\title{
Legal Protection for Customers Against Liquidation of a Bank
}

\author{
Valentino Partogi Parulian Aruan', Elvira Fitriyani Pakpahan², Mulyadi³, OK Isnainul', \\ Yusriando ${ }^{5}$ \\ \{Valent.aruan1@gmail.com1, elvirapakpahan@unprimdn.ac.id², mulyadiunpri@gmail.com³ \\ okisnainul@unprimdn.ac.id ${ }^{4}$,yusriando@unprimdn.ac.id $\left.{ }^{5}\right\}$
}

Universitas Prima Indonesia ${ }^{12345}$

\begin{abstract}
Bank is a financial institution that is trusted to store funds from the public, government and private. Protection of customers is a banking challenge that directly affects the majority of society. It is a very big challenge for banks and Bank Indonesia and the wider community to jointly create firm standards in developing customer complaint mechanisms and in realizing transparency of information on banking products. One of the important factors that led to the liquidation of a bank was the bank's eligibility rating factor as stipulated in Article 19 paragraph (1) of the Consumer Protection Law. Global Bank is responsible for providing compensation to consumers in the form of refunds or replacement of services of a similar or equivalent value.
\end{abstract}

Keywords: Legal Protection, Customers, Bank

\section{Introduction}

Bank is a business entity that collects funds from the public in the form of deposits, and distributes them to the public in the form of credit and / or other forms in order to improve the standard of living of the people at large [1]. The function of the bank is to collect funds from the public and channel it back to the community for various purposes or as a financial intermediary [2]. The collection of funds from the public is needs to be done in certain ways so that they are efficient and can be adjusted to the plans of the users of these funds. The success of a bank in fulfilling this purpose is affected, among others, by the following: Public trust, estimated income levels, risk of depositing funds, and services provided by the bank [3].

Bank is a financial institution that is trusted as a place for saving funds from the public, government and private. As the activity of saving funds between banks and customers occurs, there will be a relationship between the two parties. This relationship will be summarized in an agreement between the two parties. In the agreement, rights and obligations will arise which will be binding between the bank and the customer. Because there are rights and obligations as stipulated in the agreement, there will be legal consequences that bind the bank and the customer. Between rights and obligations there is a very close relationship, where the existence of one reflects the existence of the other. The legal relationship between a depositing customer and the bank is based on an agreement.

For this reason, of course, it is natural if the interests of the customer concerned receive legal protection as provided by law to banks. It cannot be denied that there is indeed a political will from the government to protect the interests of bank customers, especially customers who 
deposit funds. This is evidenced by the issuance of Law no. 8 of 1999 concerning consumer protection, in addition to Law no. 7 of 1992 in conjunction with Law No. 10 of 1998 which regulates banking.

About legal protection for these customers, Marulak Pardede stated that in the Indonesian banking system, protection for fund-depositing customers can be done in two ways, namely:

a. Implicit deposit protection, namely protection generated by effective bank supervision and guidance, which can prevent bank bankruptcy.

b. Explicit deposit protection, namely protection through the formation of an institution that guarantees public savings, so that if a bank fails, this institution will return public funds deposited in the failed bank. Such protection is regulated in the Decree of the President of the Republic of Indonesia No. 26 of 1998 concerning guarantees against commercial bank liabilities [4].

Protection of customers is a banking challenge that directly affects a large part of our society. Therefore, it is a very big challenge for banks and Bank Indonesia and the wider community to jointly create firm standards in developing customer complaint mechanisms and in realizing transparency of banking product information. In addition, education to the public regarding the services and products offered by banking is necessary so that the wider community can better understand the risks and benefits that will be faced in using banking services and products [5].

In accordance with the Law of the Republic of Indonesia Number 24 of 2004 concerning the deposit insurance agency which has been in effect since September 22, 2005, all thirdparty funds or deposits collected by the national bank are guaranteed by the Deposit Insurance Corporation (DIC) [6]. Before enacting Law No. 24, many people suspect that along with the implementation of the guarantee by DIC, there will be fundamental changes to third party fund collectors. This is presumably due to customers' doubts about the safety of the funds deposited in the bank. It is estimated that the customer will be in doubt as to whether the funds saved will be returned intact or will there be scouring [7].

There are still many people in rural areas who do not believe in the banking sector, especially in terms of guarantee. It is hoped that the public will no longer worry about saving at a bank, because in the event of a crisis against a bank, the public's savings will remain safe with a guarantee from the government for the full return of customer deposits. Legal protection for customers who deposit funds is in accordance with positive legal rules applicable in Indonesia as well as the rules governing deposit insurance. Such law enforcement has generated a strong trust in the community in a bank because they are sure that their savings are guaranteed.

\section{Research Methods}

Based on the description above, the problem in this study is if there is bank liquidation, what is the legal protection for customers of a bank that has been liquidated and what are the legal remedies for repayment of customer savings related to the bank liquidation. 


\section{Results and Discussion}

\subsection{General Provisions Concerning Banking and Liquidation}

Indonesian Banking Institutions consist of:

a. Central Bank is a bank that has a duty as banking supervisor. As the monetary authority, the central bank does not carry out general banking business, in the sense that it does not collect funds from the public, and does not provide credit to the public. In Indonesia, the central bank is Bank Indonesia.

b. Commercial banks are banks that carry out business activities conventionally and or based on sharia principles where one of the activities is to provide services in payment traffic.

c. Community credit banks are banks that carry out their activities conventionally or based on sharia principles, which in their activities are not allowed to provide services in payment traffic [8].

A bank can be simply defined as: "A financial institution whose main activity is to collect funds from the public and channel these funds back to the public and provide other banking services." Meanwhile, the definition of a financial institution is: "any company engaged in finance where its activities are only collecting funds or only channeling funds or both, namely collecting and distributing funds.

The legal form of a bank is regulated in Article 21 of Law No. 10 of 1998 concerning banking, namely as follows:

1. Limited Corporation;

2. Cooperative; or

3. Regional Corporation [9].

The amended Banking Law does not provide the formulation of the term "Liquidation" as mentioned in paragraphs (2) and (3) of article 37. However, if we carefully examine the provisions in paragraphs (2) and (3) of Article 37 of the amended Banking Law, the meaning of liquidation is not limited to revocation of bank business licenses, but more broadly to include the act of outbidding the bank's legal entity and the settlement or verifying of all the rights and obligations of the bank as a result of the dissolution of the bank's legal entity [10].

Zainal Asikin said that liquidation is an act to dissolve a company or legal entity. Meanwhile Van Schilfgraade and Doorhout Mees in Van de BV en de NV and Nederlands Handels en Faillissementrecht argued that "Liquidation (dissolution) is the termination of the activities of a limited corporation as a result of the end of the company's objectives." Dissolution does not have an identical meaning with the "ending" of the company's existence. The limited corporation is a legal subject owning assets and liabilities. After the dissolution is pronounced, its existence will still exist provided that its position is in the stage of liquidation (dissolution).

Rights owned by a corporation that has been dissolved must be realized and its obligations are fulfilled. The limited corporation concerned may no longer exercise its rights and obligations, and it exists as long as necessary for settlement [11]. Banking problems related to illiquid but healthy banks can be resolved by procedures and laws relating to Lender of the Last Resort standards, namely the availability of liquid collateral, temporary funding, and a decent penalty rate.

This problem can be anticipated in the Indonesian Bank Act., Meanwhile, banking problems related to unhealthy banks need to be anticipated through legislation related to exit policies (Law of the Financial Services Authority), deposit insurance (Law of the Deposit Insurance Corporation) and the liquidation process [12]. Law No. 21 of 2011 concerning the Financial Services Authority in paragraph a (1) of article 7 states "permits for bank 
establishment, opening of bank offices, articles of association, work plans, ownership, management and human resources, mergers, consolidations and acquisitions of bank, as well as bank business license revocation; and" [13].

The revocation of business license, regulation and supervision of the health of a bank is also the authority of the Financial Services Authority institution. In this case the Financial Services Authority assists Bank Indonesia in providing moral advice in the banking sector as described in the explanation of Law of the Republic of Indonesia Number 21 of 2011 concerning the Financial Services Authority.

\subsection{Bank Liquidation System and Method}

In accordance with the mandate of the Banking Law and the Indonesian Bank Law, so that the banking system can play a maximum role in the national economy, the direction of policy in the banking sector is aimed at only healthy banks that can continue to exist in business in the national banking sector, while a bank experiencing "difficulties that endanger the continuity of its business" and can no longer be saved, and / or "the condition of a bank that endangers a banking system", the bank must exit the banking system (exit policy). In the event of such a condition, Bank Indonesia is attributively authorized by law to revoke the business license of the bank concerned. However, in practice, revoking the business license of a bank is the last resort option. Article 37 paragraph (1) of Law on banking mandates Bank Indonesia to first take measures to rescue a bank experiencing difficulties that endanger its business continuity before the bank concerned must "exit" from the banking system.

If the rescue measures taken are not sufficient to overcome the difficulties faced by the bank and / or based on Bank Indonesia's assessment the condition of a bank may endanger the banking system, then a bank must exit from the banking system. Even during the existence of the National Bank Restructuring Agency, there was still a process of restructuring the banking system through the Bank of Operations Freeze and Bank of Business Freeze activities, which resulted in merged bank and bank with the revocation of its business license was recommended [14]. Since the date of the revocation of the business license, the bank concerned is obliged to close all of its offices to the public and stop all banking activities and bank management is prohibited from committing legal actions relating to bank assets and liabilities, except with the approval and / or assignment of Bank Indonesia and to:

a. Payment of outstanding employee salaries;

b. Payment of office fees;

c. Payment of bank obligations to depositors of funds using funds from the deposit insurance institution.

Bank liquidation is carried out by the Liquidation team efficiently and effectively, and it is hoped that the liquidation can be completed in a short time. The number of members of the liquidation team is a minimum of three people and a maximum of seven people, where one of them is determined by the General Meeting of Shareholders or the court to take the position of chairman who has the authority to act on behalf of the Liquidation Team. This team can consist of:

a. Other parties who are not managers or shareholders of the bank;

b. Combination of other parties with one or two people representing the management and shareholders of the bank which does not exceed one third of the total members of the Liquidation Team; or

c. Management and / or shareholders of the bank as long as the liquidation of the bank is carried out at the request of the owner and / or shareholder, with due observance of the expertise required to support the smooth running of liquidation. 


\subsection{General Provisions Regarding Customer Savings That Are Saved in a Bank}

In accordance with the times, today's society actually needs a bank as a place to deposit their money. This is because the security of funds is very much needed by the community. Savings is a form of deposit that is required by people to save money, because it is a type of deposit that can be opened with very easy and simple requirements.

There are several savings withdrawal tools depending on the respective bank, and it is up to the customer which means they prefer. These tools can be used individually or together. The tools in question are as follows:

a. Saving book; namely, a book held by the customer that contains a record of the balance of savings, withdrawals, deposits and charges that may occur. This book is used at the time of withdrawal so that it can immediately reduce the balance in the savings book.

b. Withdrawal slip; This is a withdrawal form where the customer only needs to write down the name, account number, amount of money and the customer's signature to withdraw the amount. This withdrawal slip is usually used in conjunction with the savings book.

c. Receipt; This is proof of withdrawal issued by a bank with the same function as a withdrawal slip, in which the name of the drawer, number of withdrawals, amount of money, and signature of the drawer is written. This tool can also be used in conjunction with the savings book

d. Cards made of plastic; namely a type of card made of plastic that can be used to withdraw a certain amount of money from a bank or an Automated Teller Machine (ATM). These ATM machines are usually scattered in strategic places.

In banking practice in Indonesia today there are several types of savings. The difference between these types of savings lies only in the facilities provided to savers. Thus, savers have many choices. These types are:

a. Tabanas; there are several types of tabanas such as: General Tabanas, Youth Tabanas, Student Tabanas, and Scout Tabanas;

b. Taska; namely savings linked to life insurance.

\subsection{Guarantee for The Security of Savings In The Bank}

Financial institutions that hold the trust of funds deposited from the public must continue to maintain this trust. The goal is not to harm the community so that public trust in financial institutions is lost. Apart from the community, in this case the government also experiences disadvantage because it is unable to protect its people. And the most obvious disadvantage is in the company itself, because it has carried out dishonorable practices which in the end are not trusted by the public.

More than that, with the Financial Services Authority, fraudulent practices or crimes in the financial sector can be minimized or eliminated. Therefore, the presence of the Financial Services Authority is very important, which is as important as the existence of the Corruption Eradication Commission which has succeeded in upholding the authority of the government in the field of handling corruption.

To prevent a lack of public trust in Commercial Banks, Presidential Decree Number 26 of 1998 dated January 26, 1998 was issued. Based on this presidential decree, the government guarantees payment to owners of deposits at commercial banks. This is contained in Article 1 of the Presidential Decree which reads as follows: "The government guarantees that the obligations of Commercial Banks to depositors and creditors will be fulfilled." [16]. The provisions of the Banking Law regarding the implementation of the liquidation process for banks whose business licenses have been revoked are further elaborated in Government 
Regulation No. 25 of 1999 concerning revocation of business licenses, dissolution and liquidation of banks. And the choice regarding the bank liquidation process was further strengthened by the passing of Law Number 24 of 2004 concerning the Deposit Insurance Corporation (DIC Law).

In order to deal with this dire banking condition, the government in a short time has laid down the basic principles of structuring a sound Indonesian banking financial system. These principles include: First, Bank Indonesia carried out its duties as the central bank independently, without intervention from the government or other authorities.

Second, the banking supervision function, previously carried out by Bank Indonesia, will be carried out by an independent institution. For this purpose, a Financial Services Supervisory Agency was formed whose task was not only to supervise banks, but also all nonbank institutions, namely insurance companies, pension funds, venture capital companies and financing institutions [17].

\subsection{General Provisions regarding the Guarantee of Repayment of Customer Savings Due to Bank Liquidation}

The existence of a deposit insurance agency cannot be separated from the government's efforts to increase public trust in financial institutions. In the framework of the Indonesian Economic Development in the legal sector, attention to legal guidance of, among others, guarantee institutions is needed. Legal development in the guarantee law sector is a logical consequence and a manifestation of the responsibility of legal guidance to keep pace with activities in the trade, industry, corporate, transportation, and development project sectors.

Guarantee institutions are classified as a neutral legal field that does not have a close relationship with the spiritual and cultural life of the nation. So that in such a field of law there are no objections that must be regulated immediately. Guarantee law belongs to the field of law which has recently been popularly called The Economic Law, Wiertschafrecht or Droit Econique which has the function of supporting economic progress and development progress in general.

\subsection{Repayment System of Customer Savings Due to Bank Liquidation}

The Law on the Deposit Insurance Corporation regulates the provisions regarding bank liquidation in Chapter VI. With the inclusion of the liquidation process in this law, the provisions concerning bank liquidation have become lex specialis. Several articles in the Law on the Deposit Insurance Corporation that can be stated include:

1. Article 43 provides that the Deposit Insurance Corporation acts as a liquidator, namely: In order to liquidate a Failing Bank whose business license has been revoked, the Deposit Insurance Corporation takes the following actions:

a. Exercise the authority as referred to in Article 6 paragraph (2);

b. Providing bailouts for the payment of employee salaries in the amount of minimum severance pay as stipulated in statutory regulations;

c. Take necessary actions in order to safeguard bank assets before the liquidation process begins; and

d. Decide on the dissolution of a bank legal entity, form a liquidation team, and declare the bank's status as a bank under liquidation, based on the authority as referred to in letter a.

One of the principles adopted in the Law on the Deposit Insurance Corporation in considering the implementation of failed bank rescue efforts is the least cost principle, namely that the estimated cost of rescuing is significantly lower than the cost of not rescuing the bank 
concerned; in addition, it is estimated that after being rescued, the bank will still show good business prospects.

In order to obtain funds deposited in a bank that is declared a failure which cannot be saved so that its business license is revoked, it must follow a certain process as stipulated in the Law on the Deposit Insurance Corporation. In the Law on the Deposit Insurance Corporation, it is precisely explained that: The Deposit Insurance Corporation announces the date of submission of claims for deposits that are eligible to be paid in at least 2 (two) widely circulated daily newspapers. Announcement of the date for filing a claim is carried out in stages based on the results of the completed reconciliation and verification, provided that:

a. The announcement of the first stage shall be made no later than 5 (five) working days after the reconciliation and verification begins;

b. The announcement of the last stage will be made no later than 90 (ninety) working days after the bank's business license is revoked. The Deposit Insurance Corporation also announces the terms and procedures for filing claims for deposits that are worth paying for.

Based on the above provisions, it appears that depositing customers must be patient to be verified by the Deposit Insurance Corporation whether their savings are in the proper category or not to get a refund. The criteria for whether or not a deposit is eligible for insurance from the Deposit Insurance Corporation is stipulated in the Law on the Deposit Insurance Corporation as: a guarantee claim is declared unfit for repayment if based on the results of reconciliation and / or verification:

a. Data on customer deposits is not recorded at the bank;

b. The depositing customer is the party that benefits inappropriately; and / or

c. The depositing customer is the party that causes the bank to become unhealthy.

If you pay attention to the provisions above, it can be seen that the position of the depositing customer is quite weak. Therefore, it could be that when the customer is verified the name of the customer is not recorded so that it is not eligible to pay. In an atmosphere like this, how can a customer know when making a transaction (saving) funds at the bank, whether the funds have been recorded or not, but even so he gets proof of deposit. For this reason, it is interesting what has been stated by the National Consumer Protection Agency (BPKN), in addressing the case of global banks. Based on article 19 paragraph (1) of the Consumer Protection Act, Global Bank is responsible for providing compensation to consumers in the form of refunds or compensation for services of similar or equivalent value.

The result of verification stating that there is a customer account of Bank Global which cannot be ascertained so that the repayment of deposits is not guaranteed is contrary to article 19 of the Consumer Protection Law. Meanwhile, deposits are stated as recorded at the bank if:

a. In the bank's books, there is data on the savings concerned, including the account number, the name of the depositing customer, the account balance, and other information that commonly applies to similar accounts; and / or

b. There is evidence of a flow of funds that indicates the existence of these deposits.

Deposits guaranteed by the Deposit Insurance Corporation include current accounts, time deposits, certificates of deposit, savings, and / or other equivalent forms. The guaranteed balance for each customer at one Bank is the sum of the balances of all the savings accounts of the customer at the bank concerned, both single and joint accounts. Since October 13, 2008, the guaranteed balance for each customer at one bank is a maximum of $\mathrm{Rp} 2$ billion.

For this reason, one thing that customers who deposit funds must pay attention to is that if they want their deposits to be guaranteed by the Deposit Insurance Corporation, the deposit amount does not exceed two billion rupiah in one bank and the deposit interest rate does not 
exceed the interest rate determined by the Deposit Insurance Corporation. In addition, if it is stated that a bank has failed, the customer must also pay close attention to the grace period specified in submitting a claim to the Deposit Insurance Corporation, because if the specified time limit has passed, the customer will not get a guarantee.

As explained in the Law on the Deposit Insurance Corporation, submission of guarantee claims must be made by depositing customers no later than 5 (five) years after the bank's business license is revoked. If a depositing customer does not submit a guarantee claim on his deposit, then his right to obtain a claim payment from the Deposit Insurance Corporation will no longer exist. Deposit customers whose rights have been canceled to obtain payment of insurance claims from the Deposit Insurance Corporation are treated the same as depositors whose deposits are not guaranteed, and are settled based on a liquidation mechanism.

\section{Conclusion}

One of the important factors that led to the liquidation of a bank was the bank's eligibility rating factor. The level of eligibility of a bank is determined by the CAMEL method, where CAMEL stands for Capital (for capital adequacy ratio); Assets (for asset quality ratios); Management (to assess the quality of management); Earnings (for bank profitability ratios); and Liquidity (for bank liquidity ratios). These five factors are the factors determining the condition of a bank, With the enactment of Law No. 24 of 2004 concerning the Deposit Insurance Corporation, which took effect from 22 September 2005, the regulation on guarantees for depositing customers is now in the form of a law. This institution is very important to provide legal certainty to depositors of funds in banks, in relation to the risks faced by customers due to the possibility of a rush and / or suspension of a bank's business license.

To get funds deposited in a bank that is declared a failure and cannot be saved so that its business license is revoked, it must follow a certain process as stipulated in the Law on the Deposit Insurance Corporation. The National Consumer Protection Agency (BPKN), in responding to the case of global banks, refers to article 19 paragraph (1) of the Law of Consumer Protection which stipulates that Global Bank is responsible for providing compensation to consumers in the form of refunds or replacement of services of a similar kind or equivalent in value.

\section{Suggestions}

a. It is hoped that banking officers are open to all customers who wish to open a savings account and are expected to explain the clauses that have been stated in the agreement for opening customer accounts, and it is also hoped that the public will pay attention to the provisions in opening such accounts.

b. With the existence of a deposit insurance agency, it is hoped that this institution will provide information to all customers about the soundness of a bank.

c. It is expected that customers in demanding repayment of their deposits to the liquidated bank should immediately report it to the Deposit Insurance Corporation as soon as they get the information without delay. 


\section{References}

[1] Abdullah, Thamrin dan Francis tantric, bank dan lembaga keuangan lainnya, PT Raja Grafindo Persada, Jakarta, april 2012

[2] Darmawi, Herman, Manajemen Perbankan, PT. Bumi Aksara, Jakarta Mei 2011

[3] Daruri, Ahmad Deni dan Djony Edward, BPPN Garbage in Garbage out, Center for Banking Crisis (CBC), Jakarta, Juli 2004

[4] Hermansyah, Hukum Perbankkan Nasional Indonesia, Kencana, Jakarta, 2005

[5] Kasmir, Bank dan Lembaga Keuangan Lainnya,Rajawali Pers, Jakarta, Juli 2014

[6] Marpaung, Leden, Pemberantasan dan Pencegahan Tindak Pidana Terhadap Perbankan, Djambatan, Jakarta, 2003

[7] Sipahutar, Mangasa Augustina, Persoalan-Persoalan Perbankan Indonesia, Gorga Media,Cibubur, 2007

[8] Undang-Undang Nomor 10 Tahun 1998 Tentang Perbankan

[9] Usman, Rachmadi, Aspek-Aspek Hukum Perbankan di Indonesia, PT Gramedia Pustaka Utama, Jakarta, Februari 2001, p. 167.

[10] Y. Sri Susilo, Bank dan Lembaga Keuangan Lain,Selemba Empat, Jakarta, 2000

[11] Undang-Undang Republik Indonesia No. 10 tahun 1998 tentang Perbankan

[12] Undang-Undang Republik Indonesia No. 21 tahun 2011 tentang Otoritas Jasa Keuangan 